\title{
Taxonomic Update and Habitat Status to Byttneria herbacea from Peninsular India
}

\author{
Subhash R. Somkuwar \\ Department of Botany, Dr. Ambedkar College, Deekshabhoomi Nagpur (M.S.), India
}

Received March 31, 2020; Revised April 29, 2020; Accepted May 27, 2020

Copyright $\bigcirc 2020$ by authors, all rights reserved. Authors agree that this article remains permanently open access under the terms of the Creative Commons Attribution License 4.0 International License

\begin{abstract}
Byttneria herbacea is a threatened and endemic species to Indian Peninsular region. It was earlier placed in Sterculiaceae and then a separate family Byttneriaceae. As per APG classification, it is now treated in family Malvaceae. Endemic taxa are usually more vulnerable to anthropogenic threats, natural and climate changes, and therefore hold a higher extinction risk. Taxonomic study on endemic taxa improves a basic understanding for correct identification and description. Habitat and distribution study are essential to get specific information and interpretation on current status and population dynamics of the taxon including niche requirements. It mainly contributes to several branches of applied biology. Frequent botanical exploration work was undertaken to collect the Byttneria herbacea in the forests of Peninsular India and it was identified with help of various Floras. The present study provides the information to Byttneria herbacea, which includes a detailed morphological description with data on its relevant taxonomic notes, illustration, current distribution patterns with distribution map, habitats, ecological note, population size, conservation status and threats to the selected species. The present study is the first-ever attempt at studying the taxonomic and habitat distribution aspects of Byttneria herbacea in the Indian Peninsular region. This study helps for long-term conservation and management plan of Byttneria herbacea for foresters and researchers.
\end{abstract}

Keywords Byttneria herbacea, Peninsular India, Habitat, Geographical Distribution, Taxonomy

\section{Introduction}

Byttneria Loefling, named after David Sigismund A.
Byttner (1724-1768), a physician and botanist at the University of Gottingen, Germany [1]. Byttneria Roxb. was first placed in Sterculiaceae, then a separate family Byttneriaceae. As per Angiosperm Phylogeny Group-APG-IV [2] classification Byttneria is now included in the family Malvaceae of Malvales clade. The Malvales clade also includes Malvaceae, Tiliaceae, Bombacaceae, Bixaceae, Cistaceae, Cochlospermaceae, Diegodendraceae, Dipterocarpaceae, Mutingiaceae, Neuradaceae, Sarcolaenaceae and Thymelaeaceae [2-4]. Finding of Judd and Manchester [5], Alverson, et al., [6] and Bayer, et al., [4] has led to the proposal to combine Sterculiaceae, Bombacaceae, Malvaceae and Tiliaceae into a broadly defined Malvaceae family. Contribution from molecular data, new morpho-anatomical data and progress in methodological approaches has recently led to a new broader concept of this order namely "expanded malvales”. Recent taxonomic treatments group taxa formerly included in "core malvales” in a broader concept of malvales. Additionally, the intra-familial taxonomy has been profoundly modified and in its present circumscription, Malvaceae comprises subfamilies e.g., Grewiodeae, Byttneriodeae, Tiliodeae, Bombacoideae, Malvoideae, Helicteroideae in 2 main lineages [7].

Hooker [8] initiated taxonomic study of Byttneria genus at the Indian subcontinent level and documented nine species of Byttneria genus. Byttneria andamanensis from Andaman Islands, $B$. aspera and B. crenulata reported in Nepal, B. jackiana from Penang while B. elliptica, $B$. uncinata, and B. maingayi from Malaka, B. pilosa from eastern Bengal including Burma and Chittagong of Bangladesh [8]. In independent Republic India, the genus Byttneria is composed of four species represented by $B$. andamanensis, B. aspera (Syn. grandifolia), B. herbacea and B. pilosa. Byttneria herbacea occurs in Western Peninsula, Karnataka, Orissa and Konkan [8-9]. 


\section{Materials and Methods}

Frequent botanical explorations were carried out to document and collect the Byttneria herbacea, grown in deciduous forests to moistsemi-evergreen forests of Peninsular India. To know the correct identity of the collected specimens, the Flora of British India by Hooker [8], Flora of India (Sterculiaceae) by Malick [9], An Excursion Flora of Central Tamilnadu by Matthew [10], Flora of Maharashtra by Almeida [11], Envis Bulletin, Special habitats and threatened plants of India by Botanical Survey of India (BSI) Government of India, Ministry of Environment, Forest and Climate Change [12] and eFlora of India [13] were referred. Byttneria herbacea plant species identified after keen morphological and floral observations and perusal of literature. All relevant data were recorded in a field book along with photographs and herbariums.

\section{Results}

\subsection{Taxonomic Treatment}

Byttneria herbacea Roxb., Pl. Coromandel 1:28.1795 and Fl. Brit. India 1:376

Published in: Plants of the Coast of Coromandel 1(1-2): 28, t. 29. 1795 [14]. Mast. In Hook.f. Fl. British India 1:376. 1874 [8]; Malick in Sharma et al., Fl. India 3:412, f. 115. 1993 [9].

Synonyms: Commersonia herbacea (Roxb.) G. Don

Basionym: Commersonia herbacea (Roxb.) G. Don

Family: Malvaceae Jussieu

Subfamily: Byttnerioideae Burnett

Taxonomic note: Byttneria herbacea Roxb. was earlier placed in Sterculiaceae R. Salisbury, and then a separate family Byttneriaceae R. Brown. As per Angiosperm Phylogeny Group classification [2] the genus Byttneria is now treated in family Malvaceae Jussieu.

Taxonomic description: A branched (rarely unbranched), sub-fruiticose, procumbent spreading (up to $30 \mathrm{~cm}$ ) unarmed herb with a perennial $4-10 \mathrm{~cm}$ long woody root-stock. Leaves simple, alternate distichous, ovate-oblong to ovate-lanceolate, $1.5-6 \times 1-3 \mathrm{~cm}$, apex acute to acuminate, base obtuse, rounded or sub-cordate, margin irregularly dentate, sparsely hairy, glabrous beneath; bracts 1-3, subulate,3-5 veined at base, venation actinodromous, herbaceous, sparsely hairy on both the surface, with a linear gland at base on lower side of midrib. Petiole 2.5 to $3.2 \mathrm{~cm}$ long, slender, sparsely hairy. Stipules 2.2 to $3 \mathrm{~cm}$ long, linear to subulate. Flowers bisexual, small, purple in axillary or terminal umbellate cymes. Calyx lobes basally fused, $4 \mathrm{~mm}$, oblong, linear-lanceolate, acuminate, reflexed. Petals $4 \mathrm{~mm}$, red, with long, slender tips and 2 fid appendages. Staminal tube with 5 stamens all with 5 staminoides, fertile anthers with very short filaments, staminodes ovate. Carpel stylocarpellous, stigma and style terete, Ovary pubescent, pentalocular. Capsules $0.8 \mathrm{~cm}$ across, globose, shortly spiny, septicidally 5-valved. Axile placentation. Seeds 5, one in each locule, $0.5 \mathrm{~cm}$ long, ovoid, angular, muricate.

Flowering and Fruiting: July - January

Peak Flowering and Fruiting: October - November

Life Cycle: June - January

Vernacular Names: Marathi: Madnyakalmeshwar, Piplyamul.

Oriya: Samarkhoi, Samarkhai

Bengali: Kamraj

Irula: Vipuri chedi

Telugu: Rudraksha, Yerra katla, Erra teega.

Tribal: Dikku sindur, Kamraj rahet.

Propagation: It is conventionally propagated through both seed and perennial root stock (genet).

\subsection{Status}

Byttneria herbacea plant species is threatened and endemic to Peninsular India [12, 15].

\subsection{Habitat}

Byttneria herbacea is undergrowth herbaceous and rare species found mostly in scrubby deciduous forests to moist semi-evergreen bush land, often on gallery and woodland forest, stream banks or on termite hills. It is found growing most preferably at rocky terrain on red gravelly soils along the foot hills/slopes or forest edges, under thickets forest from 800-1100 Mt. above sea level. It is fast growing species which takes $1.5-2.5 \mathrm{month} / \mathrm{s}$ to reach its reproductive stage. It shows narrow and restricted habitat range and localized by forming small cluster of its individuals. In population dynamics study of selected species in Maharashtra state, only 13 pockets of $B$. herbacea with small sub-population and less area of occupancy in its natural habitat have been observed. 


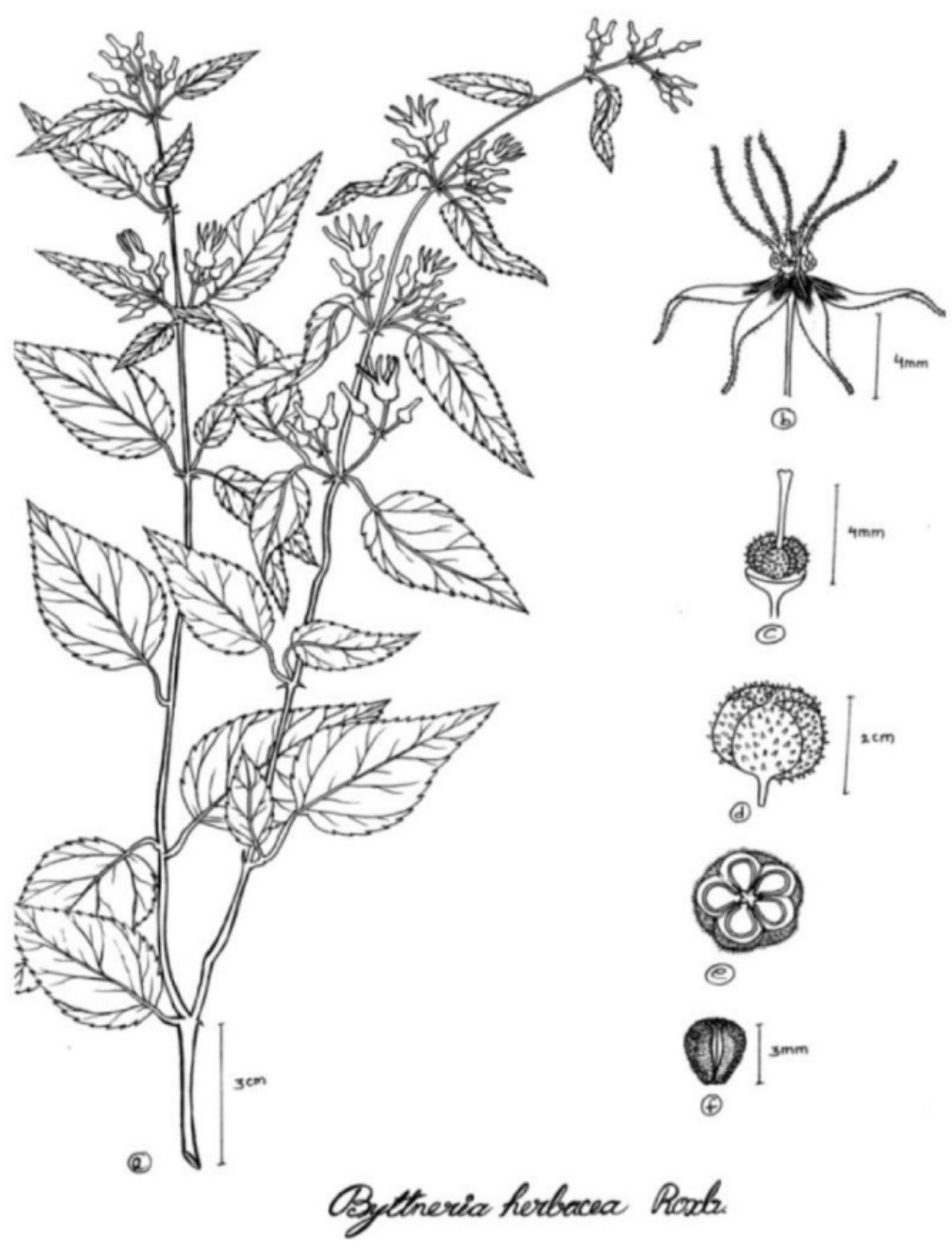

Figure 1. An Illustration of Byttneria herbacea Roxb: a: Habit, b: Flower, c: Carpel, d: Mature fruit, e: T.S of Fruit, f: seed.

\subsection{Distribution Pattern of Byttneria herbacea}

Global distribution: Envis Bulletin [12] of Wildlife Institute of India, Dehradun, India and Singh et al. [15] Botanical Survey of India has recognized Byttneria herbacea is an endemic to the Indian Peninsular region.

Indian distribution: Byttneria herbacea is distributed in Andhra Pradesh, Assam, Karnataka, Kerala,
Maharashtra, Madhya Pradesh, Nagaland, Orissa, Tamil Nadu, Telangana, Uttar Pradesh and West Bengal states of India. The selected species potentially occur in 12 states of India, but in reality, it has become threatened and restricted in very few forest pockets of Peninsular India with less number of occurrences and individuals in its sub-population. 

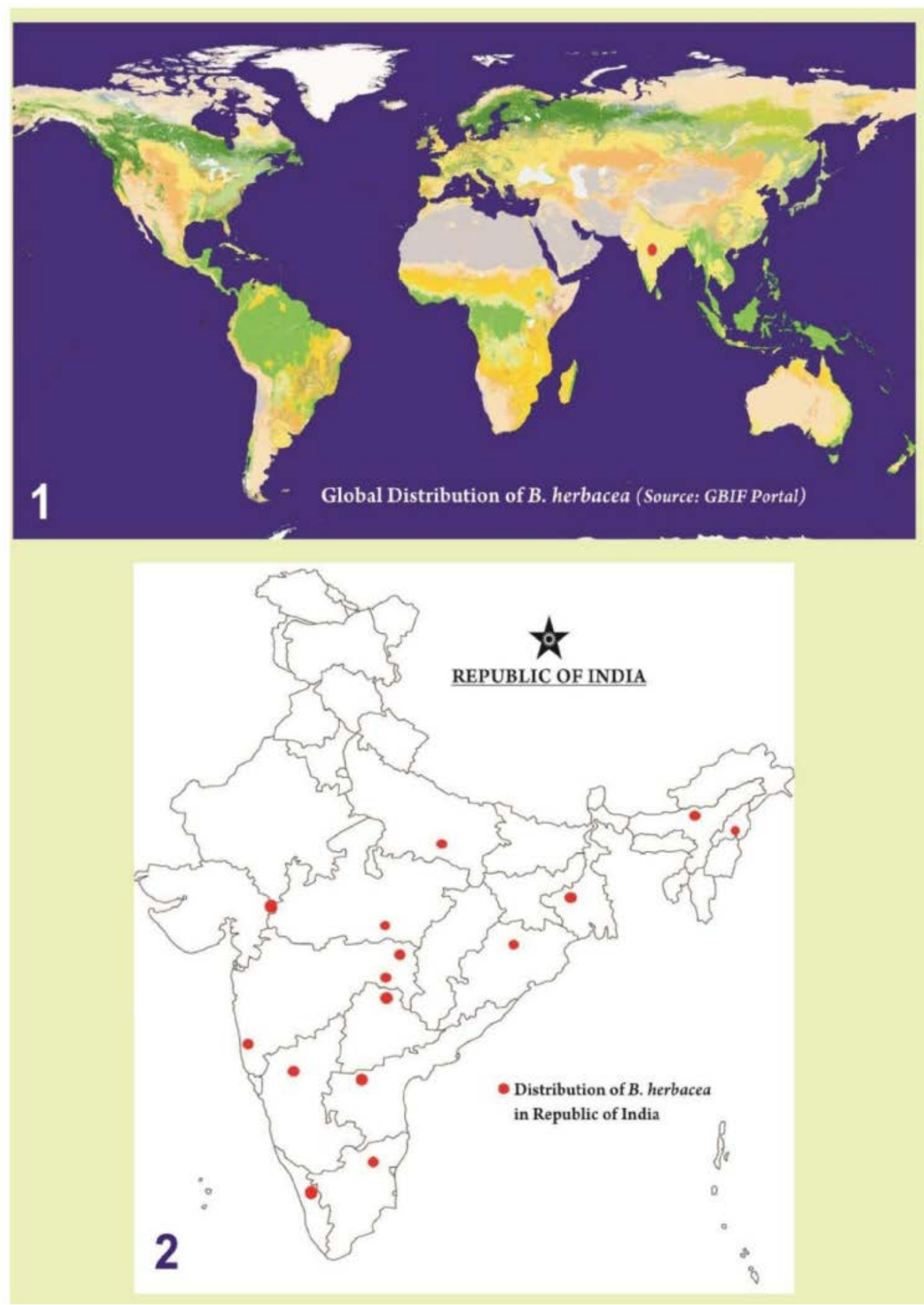

Figure 2. Distribution Pattern of Byttneria herbacea

\section{Discussions}

Endemic plants may actually be competitively inferior to other more widespread taxa [16]. The term endemic has a slightly different definition, depending on the author, e.g. according to Brown and Lomolino [17] when the term endemic is mentioned, it means that it simply does not occurs anywhere else, while in the same year Peterson and Watson in 1998 [18] stated that we should use endemic only when referring to a taxon that is restricted to a stated geographical region (either in natural or political borders). Since narrowly endemic species are threatened frequently [19] and since areas rich in endemism are more likely to be considered as a rich species area [20]. Narrow endemic 
species may harbour significantly lower genetic diversity at the population level than their widespread congeners [21-22]. Hence, endemic species may exhibit reproductive traits likely to reduce outcrossing rates, such as fewer and smaller flowers, less stigma-anther separation and lower pollen-ovule ratios [23-25]. The endemics constitute the foremost group of conservations.

A rare species is one that occurs in widely separated small sub-population so that inter-breeding between sub-populations is seriously reduced or restricted to a single population [26]. They are not at present endangered or vulnerable but face a high risk of being so and usually localized within restricted geographical areas or habitats or are thinly scattered over a more extensive range [27]. A hypothetical rare species is one with narrow habitat range, low climate tolerance; specialized adaptation requiring an outside agency for pollination, poor dispersal strategies, few seeds per fruit and poor viability of seeds [28]. Distribution study of threatened and endemic plant taxa provides insights for prioritizing such plant species conservation as well as processing the mechanisms of distribution patterns. Site containing national endemic and threatened species is more important for distribution study.

The outputs of floristic modelling and assessment can be used to improve understanding on conservation and protection of threatened plant species over the range in a suitable habitat [29] as well as identification of areas that represent biological species richness and endemic taxa [30]. Study on distribution and status of threatened and endemic species provides valuable data helps in conservation decisions for ecologists and conservationists. The ability to completely sample large areas in order to assess distribution is often difficult, hence smaller sampling areas to be used to make predictions about the distribution of a species over a larger area based on geographic and environmental predictor variables.

Byttneria herbacea Roxb. was earlier placed in Sterculiaceae and then a separate family Byttneriaceae. Edlin [31] divided the family Sterculiaceae into two tribes: Sterculineae containing only Sterculia and Tarrietieae which included Tarnetia and Heritiera. In Buettneriaceae Edlin [31] included other genera such as Pentapetes, Melochia, Commersonia, Buettneria, Leptonychia, Abroma, Pterospermum, Helicteris and Kleinhouia. In the broader APG [2] circumscription, Malvaceae sensu lato corresponds to the four traditional plant families Malvaceae sensu stricto, Bombacaceae, Sterculiaceae and Tiliaceae. Thus, the family Malvaceae has expanded to include 250 genera and has been divided into nine subfamilies, one of which is Malvaceae sensu stricto [4-5]. These families are closely related to Malvaceae sensu stricto but they are not monophyletic groups as shown by numerous researchers on the Malvales [5, 32-34]. The broad circumscription of the family, as mentioned above, is defined as core Malvales in the Cronquist system. This classification has been adopted by [4, 32-34, 36-37]. Hinsley [38] has put several alternatives for a new classification of Malvaceae (core Malvales).

According to Cronquist [39] the order Malvales includes four polypetalous dicotyledonous families such as Malvaceae sensu stricto, Bombacaceae, Sterculiaceae and Tiliaceae. Bentham and Hooker [40] have placed Malvaceae sensu lato, Sterculiaceae and Tiliaceae families under the order Malvales. While Hutchinson [41-42] considered that the order Malvales should contain only Malvaceae as the order Malvales is more advanced than Tiliales and hence the families Sterculiaceae, Tiliaceae and Bombacaceae are treated under Tiliales. Bentham and Hooker [40] and Hutchinson [43] have placed the genus Byttneria (also spelled as Buettneria) under the tribe Byttnerieae in Sterculiaceae family but Takhtajan [44] has placed it under the tribe Byttnerieae of the subfamily Byttnerioideae of Sterculiaceae family.

Molecular phylogenetic studies (chloroplast $n d h F$ gene-aligned length $2226 \mathrm{bp}$; $r b c L$ sequence data) have shown that the traditional dicotyledonous families such as Malvaceae sensu stricto, Sterculiaceae, Tiliaceae and Bombacaceae are closely related and thus these families are merged into a more circumscribed family Malvaceae sensu lato under the core 'Malvales' (APG-III) [3]. Judd and Manchester [5] studies states that Malvaceae sensu stricto is monophyletic in origin while Bombacaceae, Sterculiaceae and Tiliaceae are not monophyletic which supports the view of Edlin [31]. As a result, those genera once placed under Sterculiaceae family are treated under subfamilies like Byttnerioideae. The members of Byttnerioideae clade show (i) a general reduction of stamen number compared to Grewioideae and other putative groups (ii) the fertile stamens are gathered into antipetalous fascicles and if staminodes present are antisepalous and (iii) the petals are broad or concave at their base. Further, the $r b c L$ sequence data suggests that the separation of Byttnerieae and Theobromeae tribes of subfamily Byttnerioideae from the rest of traditional Sterculiaceae family as predicted by Edlin [31] is accepted by Whitlock, et al., [45], Alverson, et al., [46] and Bayer, et al., [36]. Based on stem structure, vegetative organs, flowers, schizocarpic fruit and spiny pollen grains character, Edlin [31] has created a new family Buettneriaceae by dividing the tribes traditionally placed in Sterculiaceae into two families: Sterculiaceae sensu stricto (Sterculieae) and Byttneriaceae (remaining tribes). Cronquist [39] however, stated that the Byttneriaceae is still quite heterogeneous (in morphology, anatomy, and pollen features) and is paraphyletic or polyphyletic. 
Table 1. Table showing classification of the Genus Byttneria by different authors

\begin{tabular}{|c|c|c|c|c|c|}
\hline & $\begin{array}{c}\text { Bentham \& } \\
\text { Hooker-1862-1883 [40] }\end{array}$ & $\begin{array}{c}\text { Masters-1874 [53] \& } \\
\text { Hutchinson-1967 [54] }\end{array}$ & $\begin{array}{c}\text { Takhtajan-1997 } \\
{[44]}\end{array}$ & $\begin{array}{c}\text { Cronquist-1988 [50] \& } \\
\text { Mabberley-2008 [51] }\end{array}$ & APG-IV 2016 [2] \\
\hline Family & Sterculiaceae & Sterculiaceae & Sterculiaceae & Malvaceae & Malvaceae \\
\hline Subfamily & - & - & Byttnerioideae & Byttnerioideae & Byttnerioideae \\
\hline Tribe & Buettnerieae & Buettnerieae & - & - & - \\
\hline
\end{tabular}

Thorne [47] has divided the family Sterculiaceae into two subfamilies namely Sterculioideae and Dombeyoideae. Thorne [47] system gives family status to Byttnerioideae and hence the subfamily Byttnerioideae is elevated to family level Byttneriaceae. Takhtajan [44] has also accepted this classification but he further subdivided these two subfamilies into a series of tribes. But the recent version of the Thorne system [48] takes an intermediate approach in combining Bombacaceae and Sterculiaceae under Malvaceae sensu lato, but retaining Byttneriaceae (containing traditional Sterculiaceae and Tiliaceae) and a considerably restricted Tiliaceae as separate families. Whitlock, et al., [49] have considered Dombeyoideae as a distinct family Byttneriaceae. In fact, the family Sterculiaceae is very diverse and is characterized by a great diversity of morphological, anatomical and palynological features, particularly between Byttnerioideae and Sterculioideae. Since the molecular phylogenetic studies (both $r b c L$ sequence data and chloroplast $n d h F$ gene analysis) have confirmed that the traditional family Sterculiaceae is one among the elaborated family Malvaceae sensu lato and the subfamily Byttnerioideae is a separate clade in Malvaceae sensu lato family where the genus Byttneria belongs to and not under Sterculioideae clade.

As per embryological observation carried out in the present study, Byttheria herbacea has circinotropous ovules. Circinotropous ovules are not observed earlier by any researchers in the of Sterculiaceae and Malvaceae family members. Therefore, Byttheria genus deserves critical analysis for proper taxonomic placement. As per Cronquist [50], Takhtajan [44], Mabberley [51] and Angiospermic Phylogenetic Group [2-3, 52] classification system the family status of Byttneriaceae merged under Malvaceae. I still support the view of Cronquist [50], Takhtajan [44], Mabberley [51] and APG [2-3,52] classification system.

\section{Conclusions}

Habitat loss and unchecked business of wild endemic medicinal plants is threatening the future of essential resources, as well as the beauty, diversity and natural heritage of our green planet earth. As natural habitats are destroyed or degraded, we lose many unique and precious endemic species of plants every year from the wild habitat. This loss of diversity may also take with it important cures for diseases-both those face by us now and those that may emerge in the future. Conservation of existing wild habitat of endemic and threatened medicinal plant species are very essential to minimize or avoids the loss of these endemic plant resources. Sustainable use and ex-situ propagation and cultivation methods are already being suggested by the Convention on International Trade in Endangered Species of Wild Fauna and Flora (CITES), the Convention on Biological Diversity, the National Center for the Preservation of Medicinal Herbs, International Standard for Sustainable Wild Collection of Medicinal and Aromatic Plants (ISSC-MAP), the Medicinal Plant Working Group and other organizations. The present study is the first-ever attempt at studying the taxonomic aspects and habitat distribution study of Byttneria herbacea in the Indian Peninsular region. This study helps for long term conservation and management plan of Byttneria herbacea for foresters and researchers. Further studies in view of embryological context are likely to yield more comprehensive results to improve fundamental understanding systematics of Malvaceae family members.

\section{Acknowledgements}

The author is gratefully acknowledging Dr. Alka Chaturvedi former Head P.G.T.D. Botany RTMN University Nagpur (MS) India for her advice on nomenclatural issues and taxonomic help. The author thanks Dr. Rahul Kamble Dept. Botany, Dr. Ambedkar College Deekshabhoomi, Nagpur (M.S.), India and Dr. J. V. Gadpayle Dept. of Botany S. N. Mor College Tumsar (MS) India for their useful suggestions and for extensive assistance during field excursions. Special thanks to the Forest Department for permission to conduct distribution and habitat survey on Byttneria herbacea. I thank the reviewers for their insightful and constructive comments that substantially improved the manuscript.

\section{REFERENCES}

[1] V. H. Heywood. Global biodiversity assessment. Cambridge University Press, 174-185, 1995.

[2] APG-IV. An update of the Angiosperm Phylogeny Group 
classification for the orders and families of flowering plants; APG IV. Bot. J. Linn. Soc. 181, 1-20, 2016.

[3] APG. An ordinal classification for the families of flowering plants. Annals of the Missouri Botanical Garden 85, 531-553, 1998.

[4] C. Bayer, M.F. Fay, A.Y.D. Bruijn, V. Savolainen, C.M. Morton, K. Kubitzki, W.S. Alverson, M.W. Chase. Support for an expanded family concept of Malvaceae within a recircumscribed order Malvales: a combined analysis of plastid atpB and rbcL DNA sequences. Botanical J. of the Linnean Society, 129, 267-303, 1999.

[5] W. S. Judd, S. R. Manchester. Circumscription of Malvaceae (Malvales) as determined by a preliminary cladistic analysis of morphological, anatomical, palynological, and chemical characters. Brittonia, 49, 384-405, 1997.

[6] N. C. Bayer, D.A. Baum. Phylogeny of the core Malvales: Evidence from ndhF sequence data. American J. of Botany 86, 1474-1486, 1999.

[7] Sanyal Sanghamitra. Morpho-taxonomic studies of some members of Malvales (Cronquist, 1981) occurring in Salt lake City, North 24 Parganas, West Bengal, Int. J. of Innovative Res in Sci. Engineering and Tech. 5 (5), 8564- 8572, 2016.

[8] J. D. Hooker. The Flora of British India, Vol. 1: London: 376, 1872.

[9] K. C. Malick. Sterculiaceae, In: Sharma, B.D. and Sanjappa, M. (eds), Flora of India, Vol. 3, Botanical Survey of India, Calcutta,1993.

[10] K. M. Matthew. An Excursion Flora of Central Tamilnadu, India. Oxford and IBH Publishing Co. Pvt. Ltd., 1991.

[11] M. R. Almeida. Flora of Maharashtra, Orient Press, Mumbai: 133, 1996.

[12] Envis Bulletin. Special habitats and threatened plants of India: Wildlife and Protected Areas, Vol.11 (1), Printed by Wildlife Institute of India, Chandrabani, Dehradun, 2008.

[13] MoEFCC-BSI. eFlora of India. http://efloraindia.nic.in/efl oraindia/taxon List. action?id=3313andtype=4, 2015.

[14] Byttneria herbaceaRoxb. Published in: Pl. Coromandel 1: t. 29. 1795 source: Catalogue of Life. https://www. gbif.org/species/3668959.

[15] P. Singh, K. Karthigeyan, S. S. Dash. Endemic vascular plants of India. Botanical Survey of India-Kolkata, 2015.

[16] M. Kessler. Maximum plant-community endemism at intermediate intensities of anthropogenic disturbance in Bolivian montane forests. Conservation Biology, 15, 634-641, 2001.

[17] J. H. Brown, M.V. Lomolino. Biogeography, $2^{\text {nd }}$ edn. Sinauer Associates, Sunderland, Massachusetts, 1998.

[18] A. T. Peterson, D. M. Watson. Problems with areal definitions of endemism: the effects of spatial scaling. Diversity and Distributions, 4, 189-194, 1998.

[19] S.W. Laffan, M.D. Crisp Assessing endemism at multiple spatial scales, with an example from the Australian vascular flora. Journal of Biogeography, 30, 511-520, 2003.

[20] R. M. Cowlinga, R. L. Presseyb, M. Rougetc, A.T. Lombard. A conservation plan for a global biodiversity hotspot-the Cape Floristic Region, South Africa, Biological Conservation, 112, 191-216, 2003.

[21] J. D. Karron. A comparison of levels of genetic polymorphism and self-compatibility in geographically restricted and widespread plants congeners. Evol. Ecol., 1 (47) 58, 1987.

[22] A. G. Matthew, Pamela S. Soltis. Patterns of genetic variation in rare and widespread plant congeners. American Journal of Botany, 87(6), 783-792, 2000.

[23] R.W. Cruden. Pollen-ovule ratios: a conservative indicator of breeding systems in flowering plants. Evolution, 31, 32-46, 1977.

[24] R.E. Preston. Pollen-ovule ratios in the Cruciferae. American Journal of Botany, 73, 1732-1740, 1986.

[25] J. Brunet, C.G. Eckert. Effects of floral morphology and display on outcrossing in Blue Columbine, Aquilegia caerulea (Ranunculaceae). Funct Ecol, 12, 596-606, 1998.

[26] W. H. Drury. Rare species. Biological Conservation, 6, 162-169, 1974.

[27] IUCN. Plant Red Data Book, IUCN Publications, Switzerland, 1978.

[28] M. P. Nayar. Hot spots of endemic plants of India, Nepal and Bhutan, The Director, TBGRI, Trivandrum, p. 252. 1996.

[29] A. R. Marshall, P. J. Platts, R. E. Gereau, W. Kindeketa, S. Kang'ethe, R. Marchant. The genus Acacia (Fabaceae) in East Africa: distribution, diversity and the protected area network. Plant Ecology and Evolution, 145 (3) 289-301, 2012.

[30] S. Williams. The identification and conservation of important plant areas: A case study from the Turks and Caicos Islands. M.Sc. Thesis. Imperial College London, 2009.

[31] H. L. Edlin. A critical revision of certain taxonomic groups of Malvales, parts 1 and 2. New Phytologist, 34, 1-20, 122-143, 1935.

[32] D. A. Baum, De Witt Smith S., A. Yen, W. S. Alverson, R. Nyffeler, B. A. Whitelock, R. L. Oldham Phylogenetic relationships of Malvatheca (Bombacoideae and Malvoideae; Malvaceae sensu lato) as inferred from plastid DNA sequences, American J. of Botany, 91, 1863-1871, 2004.

[33] A. Perveen, E. Gafstrom, G. El-Ghazaly. World Pollen and Spore Flora 23. Malvaceae Adams. subfamilies: Grewioideae, Tilioideae, Brownlowioideae, Grana, 43, 129-155, 2004.

[34] A. Tate, F. Aguilar, J. Wagstaff, J.C. La Duke, A. Bodo Slotta, B. Simpson. Phylogenetic relationships within the tribe Malveae (Malvaceae, subfamily Malvoideae) as inferred from ITS sequence data. American J. of Botany, 92, 584-602, 2005. 
[35] W.K. Taia. General view of Malvaceae Juss. S.L. and taxonomic revision of genus Abutilon Mill. In Saudi Arabia, JKAU Sci. 21 (2), 349-363, 2009.

[36] C. Bayer, K. Kubitzki. Malvaceae. In: Kubitzki, K. and C. Bayer (eds.), Flowering Plants, Dicotyledons: Malvales, Capparales and Non-betalain Caryophyllales, 225-311. Springer-Verlag, Berlin, Germany, 2003.

[37] P. M. Maas, L. Y. Westra. Neotropical Plant Families, (3 ${ }^{\text {rd }}$. Ed.), Net page, 2005.

[38] S. R. Hinsley. Classification of Malvaceae: Overview, compostion: Position: Division. Malvaceae Info (Home), 2006.

[39] Cronquist. An integrated system of classification of flowering plants. Columbia University Press, New York, NY, 1981.

[40] G. Bentham, J. D. Hooker. Genera Plantarum. Vol. 1. London, Lovell Reeve, 1865.

[41] J. Hutchinson. The families of flowering plants vol. $1^{\text {st }}$ Dicotyledons ( $2^{\text {nd }}$ ed.) claredon Press Oxford, England, 1959.

[42] J. Hutchinson. Evolution and phylogeny of flowering plants Dicotyledons: Facts and Theory. Academic Press London and New York, 1969.

[43] J. Hutchinson. The families of flowering plants. Clarendon Press, Oxford, 1973.

[44] A. Takhtajan. Diversity and classification of flowering plants. Columbia University Press, New York, 1997.

[45] B. A. Whitlock, A. M. Hale. The phylogeny of Ayenia, Byttneria and Rayleya (Malvaceae) and its implications for the evolution of growth forms. Systematic Botany, 36 (1),
129-136, 2011.

[46] W. S. Alverson, K. G. Karol, D. A. Baum, M. W. Chase, S. M. Swensen, R. McCourt, K. J. Sytsma. Circumscription of the Malvales and relationships to other Rosidae: Evidence from rbcL sequence data. American J. of Botany 85, 876-887, 1998.

[47] R. F. Thorne. Classification and geography of the flowering plants. Bot. Rev. (Lancaster) 58, 225- 348, 1992.

[48] R. F. Thorne. The classification and geography of the flowering plants: dicotyledons of the class Angiospermae. Botanical Review, 66, 441-647, 2001.

[49] Whitlock et al., B. A. Whitlock, C. Bayer, D. A. Baum. Phylogenetic relationships and floral evolution of the Byttnerioideae ("Sterculiaceae" or Malvaceae s.l.) based on sequences of the chloroplast gene ndhF Syst. Bot., 23 (2001), 420-437, 2001.

[50] A. Cronquist. The evolution and classification of flowering plants. $2^{\text {nd }}$ edition. N.Y.B.G., New York, U.S.A., 1988.

[51] D.J. Mabberley. Mabberley's plant-book: a portable dictionary of plants, their classification and uses. $3^{\text {rd }}$ ed. [second reprint with corrections, 2014]. Cambridge: Cambridge University Press, 2008.

[52] APG III An update of the Angiosperm Phylogeny Group classification for the orders and families of flowering plants. APG III. Botanical Journal of the Linnean Society,161, 105-121, 2009.

[53] M.T. Masters. Sterculiaceae. In: Hooker, J.D. (ed.), The Flora of British India, Vol. 1. L. Reeve and Co. London, 353-379, 1874.

[54] J. Hutchinson. The genera of flowering plants, vol. 2. Clarendon Press, Oxford, 1967. 